\title{
WHAT IS SO SPECIAL ABOUT MANGROVES?
}

\author{
VANNUCCI, $\mathrm{M}$. \\ International Society of Mangrove Ecosystems, ISME, c/o Faculty of Agriculture, University of the Ryukyus, \\ CEP 903-0129, Nishihara, Okinawa, Japan \\ Correspondence to: Marta Vannucci, Av. Jacutinga, 607, CEP 04515-030, São Paulo, \\ SP, Brazil, e-mail: drvannucci@hotmail.com
}

Received November 7, 2000 - Accepted November 27, 2000 - Distributed November 30, 2001

\begin{abstract}
The title question of this short paper has been addressed to me countless times by persons from all walks of life. The paper is a concise answer to the question; it might go halfway towards satisfying the questioners, but not more than halfway. This paper identifies the uniqueness of mangrove ecosystems in that they are created and sustained by a small number of rooted vascular plants in the intertidal area of the tropics. In addition to being a marginal ecosystem, a mangrove is unique in that, as an ecosystem it has various interactions with other ecosystems, both adjoining and remote in space and time. Another unique feaure of mangroves is that, unlike most marginal ecosystems, they are highly productive and dynamic. Healthy mangrove ecosystems also have the peculiar ability to immobilize heavy metals.
\end{abstract}

Key words: marginal ecosystems, productivity, heavy metals, paleontology, adaptations, tides.

\section{RESUMO}

\section{O que há de tão especial em relação aos manguezais?}

A pergunta formulada no título foi dirigida à autora por várias pessoas de todos os tipos e afazeres. A presente nota é uma tentativa de resposta, a fim de satisfazê-las ao menos em parte. Uma resposta curta não poderia atender a mais do que uma fração da pergunta, pois, necessariamente, deve ser concisa. Este texto identifica a principal peculiaridade dos manguezais no fato de serem criados e mantidos por um pequeno número de plantas vasculares arraigadas no solo da faixa tropical entre marés. O manguezal é um ecossistema marginal com grande e variado número de interações com outros ecossistemas, próximos, adjacentes ou remotos no tempo e no espaço. Outra particularidade é que, diferentemente da maioria dos ecossistemas marginais, é um sistema altamente dinâmico, muito produtivo e com capacidade de imobilizar sais de metais pesados.

Palavras-chave: ecossistemas marginais, produtividade, metais pesados, paleontologia, adaptações, marés.

\section{INTRODUCTION}

As a matter of fact there is nothing special about mangroves except unique that they are marginal ecosystems uniquely well defined in space with boundaries marked by high and low tide levels. There are few other ecosystems so defined in space, but some others could be mentioned, e.g., a penguin rookerie, an isolated alpine meadow, a seagrass bed, a seasonal river (wadi), an oasis in the desert, or a deep sea vent. All of these and others are, ecologically speaking, unique because they are marginal ecosystems, in the sense that the species of plants and animals integrating them are all living very near the limits of tolerance to extreme environmental conditions. The various environmental factors and their fluctuations determine the survival or death of the individuals of the various species. Consequently, biodiversity is low in marginal 
ecosystems because few species tolerate extremes of temperature, salinity, winds, solar radiation, aridity, flooding, and other factors and their fluctuations which are often violent and frequent. For these reasons marginal ecosystems are vulnerable and fragile and, among them, mangrove ecosystems are unique.

In such ecosystems usually one or very few species of plants or, more rarely, one or very few species of animals at each particular site are more numerous than others, and thus become the dominant species of the particular system. This applies to all marginal ecosystems, whether terrestrial, aerial, aquatic, polar, temperate, or tropical. Dominant species of particular ecosystems are for instance sea otters in the kelp beds off the California coast, or Heritiera fomes, Excoecaria agallocha, Avicennia marina or A. officinalis, or any Rhizophora sp. or Bruguiera sp. in different mangroves.

Although mangroves are unique marginal ecosystems, this alone does not make them special. Mangrove stands, even if only isolated groups of just a few mangrove trees are immediately identifiable as a mangrove, whether they occupy many hectars of wetlands or just a tiny coastal tidally-inundated pool of brackish water. The species of mangroves, like those of other marginal ecosystems, can tolerate extreme environmental conditions a which enables them to keep out by competitive exclusion other species of plants and animals that do not tolerate such extremes. For instance: guano islands exist because a few species of fishing sea birds can build their nests on high rocky scarps next to fish-rich waters; the same principle applies to penguin rookeries which are similarly placed near fishrich waters next to ice-covered land or sea, because penguins cannot live on high rise scarps; the limiting factor for penguins is the need for flat surfaces for breeding purposes. Depending on climate, land conditions, or human impact, dominant species of mangrove vegetation and animals vary. There are vicariant species from one site to another, for instance, there could not be Royal Bengal tigers in the mangroves bordering the Atlantic Ocean or dominant Heritiera spp. We find instead raccoons and local species of otters among the carnivores and species of Rhizophora other than those of the Indo-Pacific mangroves. The Atlantic Ocean mangrove species of plants and animals, occupy ecological niches corresponding to those occupied by tigers and Heritiera or other species of Rhizophora in the Indo-Pacific.

Mangroves are unique because they are a gift of the tides along low-lying tropical and occasionally subtropical coastal areas, along the margins of estuaries, deltas, coastal lagoons, and brackish tidal waters in general. There are no mangroves where there are no tides or where tidal amplitude is reduced as, for instance, in the Mediterranean Sea, though there were mangroves in the Tethys Sea in past geological Eras.

In mangroves as in other marginal ecosystems, biodiversity is low. A mangrove forest is dominated by a few woody halophytes found exclusively in that ecosystem. Paleontologically, the earliest ancestors of mangrove species occur the Tertiary; evolution took a long time to reach the present roughly ninety species of vascular plants limited to mangrove swamps. The interesting aspect of the evolutionary history of mangrove plants is that they belong to a variety of botanical families, but only one family, the Rhizophoraceae, is exclusively found in mangroves, while the fam. Avicenniaceae acquired genera and species from the mangroves. Palmae were perhaps the first order to adapt to the intertidal conditions; paleontological studies reveal that Nypa fruticans probably existed already in the Upper Tertiary and certainly in the early Quaternary. Nypa fruticans is the only palm tree at present found solely in the mangroves of the Indian and Western Pacific Oceans, though fossils of this species have been found in Northeast Brazil, London clay, and elsewhere in Europe. The Nipa palm is at present also found in West Africa where it was introduced last century and has become so well adapted as to be now considered a pest. Phoenix paludosa is an upper-mangrove species although not exclusively, that, may be found in areas of very low salinity or fresh water adjacent to mangroves. The small number of species of vascular plants that have become genotipically adapted to brackish water swamps, suggests that overcoming ecological barriers was a difficult evolutionary feat. This is further confirmed by the fact that over the Tertiary and Quaternary Eras, only very few species could overcome the barriers and 
themselves establish as species. The genotype of "good" mangrove species is very labile; the intraspecific variation is great, but how well are the various lineages or sub-species or varieties of the species of, for instance, Avicennia or of Rhizophora, genotipically isolated? Very little indeed is known of the genetics of mangrove plants. The success of exclusively mangrove species must necessarily be linked to a very labile genotype capable of rapid adaptation to a great variety of environmental situations.

Another aspect of mangrove vegetation is that adaptation to a very special environment has induced unique morphological and physiological features, such as: peculiar branching and rooting systems; special reproductive strategies such as viviparity and dispersal of seeds and propagules by water currents; a variety of mechanisms to anchor the plant into a semifluid substratum; and selectivity of absorption or rejection of various salts and other compounds. The mechanisms for avoidance of salinization and death of living tissues are either salt exclusion by differential absorption and excretion at root or leaf levels, or by immobilization in hypersaline vacuoles or special storage tissues. These mechanisms have been throughly studied and are dealt with in the specialized literature and elsewhere.

Mangrove forests at their best are impressively tall, evergreen forests whose ground is alternately flooded or exposed to air, covered or uncovered by waters of varying salinity, according to local tidal and seasonal cycles. There are throughout the world non-mangrove forests that stand in fresh water, for instance the immense Amazon Forest which is half the year under water and half the year above it, the permanently submerged cypress forest of parts of the Northern rim of the Gulf of Mexico, and the higher reaches of such extensive mangrove forests as those of the delta of the Ganges-Brahmaputra, the Sunderbans, which are inundated seasonally and otherwise stand on almost dry soil. Mean sea level in these and other monsoon areas may vary by one meter or more between the monsoon and intermonsoon season so special physiological adaptations are needed to tolerate both prolonged immersion or emersion.

The features of mangrove vegetation, its foliar and bark anatomy and histology, phenology and physiology are the result of aeons of evolutionary adaptation to a unique type of environment: this is why mangroves are a unique ecosystem. The process of adaptation to local environmental conditions continues everywhere, from the Pacific Ocean islands to the coastlines of India, Africa, South and Southeast Asia, Australia, New Zealand, and Brazil.

Viviparity is typically attributed to mangrove species. Species of the fam. Rhizophoraceae are viviparous and common, and the genus Rhizophora is present practically everywhere and stands out because of its stilt and buttresss roots. However, only a small percentage of exclusive mangrove species are viviparous. Viviparity occurs also in land species of plants, specially so in cultivated varieties subject to intensive selection, such as apples, oranges, papaya, and others whose seeds germinate while still in the fruit. Viviparity is extremely rare in wild species of phanerogamous plants; cultivation and intense breeding selection appear to induce viviparity. This suggests that the adaptation of mangrove species to the very selective brackish, swampy, intertidal environment has induced or favored viviparity. Viviparous varieties of fruits produced by artificial selection could be compared to viviparous species or varieties produced by natural selection in the physiologically demanding natural environment of tidal flats.

Mangrove vegetation is poor in number of species rooted in the substratum; there is, however, a relatively rich diversity of epiphytic and parasitic flora of algae, lichens, higher fungi, nonvascular and vascular plants, plus Bromeliaceae in the Americas and Loranthaceae in Asia. Biologically all these are a non-mangrove flora which uses trees and shrubs as a convenient substratum, irrespective of ground or soil on which support trees occur; they are not exclusive to the mangrove ecosystem. Mangrove microorganisms are dominated by the Cyanophyceae or blue-green algae, diatoms, lower fungi, and others and the ubiquitous ferri - and thiobacilli responsible for solubilization of organic matter and nutrient cycling. Mangrove soils have recently been proved to promote storage of heavy metals (Lacerda, 1998).

Mangrove fauna presents an entirely different picture. There are extremely few animal 
species exclusive to mangroves. Many are imperfectly known species of microfauna, among which are the Kynorhyncha, Gastrotricha, Amphipoda, and Nematoda, Anellida and Molluscs all live in the warm, and wet or humid upper layers of the soil and in the rhizosphere, are represented in the mangroves. All orders of vertebrates including residents and occasional visitors, among them mammals, like dolphins, carnivores, deers, and monkeys; nesting and migratory birds; resident reptiles and amphibians like crocodiles, gavials, snakes, frogs and all sorts of fishes and their fry inhabit mangroves. Of course, they are never all present at the same time in one place: each mangrove stand has its typical fauna. Among the invertebrates however, there is a great relative abundance and wide distribution of molluscs, decapod crustaceans, and insects of a variety of orders, inhabiting permanently or temporarily the mangroves of the world. And man, of course is in many places, specially in South or Southeast Asia, some parts of Northern South America and some larger Pacific Ocean islands, as a permanent inhabitant or regular visitor.

In evolutionary terms, the fauna of the mangroves is typically opportunistic and not a group of species specially adapted to the mangrove environment. Many are visitors or temporary residents taking advantage, like man, of the high productivity of the system to satiate themselves on the many anadromous and catadromous species of fish and crustaceans there are grass-eating deer, or those who use the sheltered, warm, and food-rich mangrove waters to reer their young. Even camels traditionally visit certain mangrove islands when the grass Porteresia coarctata is at its best, to drop their young in the centers of saucer-shaped mangrove islands, like Aliabet Island in the estuary of the river Narmada, in Gujarat, India. The plankton, benthos, and borers of the mangrove swamps are in general the same, down to species level, as those in the brackish waters in the of same geographical area. Very few, if any, animal species are exclusive to the mangroves, rather they are typical of harsh ecosystems where selective adaptation to variable environmental conditions takes place unendingly.

Animals are of two sorts: sessile and mobile. The mobile animal species come and go with the tides, river flow, coastal currents, and winds. As parasites, their eggs and spores carried by organic debris and larger animals, they all come and go according to their specific response to the environment for feeding and breeding. The sessile fauna faces the same ecological constraints as rooted plants. The survival strategy adopted by most animals, like barnacles and most sessile or semisessile molluscs, is to close the operculum or the valves hermetically and lower tissue metabolism during the tidal or seasonal periods when environmental conditions are unfavorable and they lie above or under water. Some mobile animals like various crabs, climb up and down tree trunks following tidal movements. Many animals are poikilosmotic, meaning that the ionic concentration of their body fluid varies according to salinity of the surrounding water. Such physiological mechanisms enable these species to lead an active life even under unfavorable environmental conditions. On the other hand, homeosmotic animals, unable to adapt quickly enough to changing environmental salinity, inevitably must lock themselves up during unfavorable conditions.

What is the difference between mangrove plants and animals in terms of biodiversity? Vascular plants are anchored in a semifluid substratum to which they had to become adapted or disappear as a species. This is a fact that emerges from paleontological evidence. A large number of plant species succumbed during the evolutionary process, or took another direction. Epiphytic flora, on the other hand, is brought to the mangroves by winds, animal droppings, insects, birds, or bats. Thus rather than regular members of the ecosystem, though frequent and common, they are visitors or inhabitants contributing little to the structure and dynamics of the ecosystem, except when they become pests. The mobility of animal species enables them to adapt to varying environmental conditions, to move along with their specific ecological niche as the niche itself moves. Tidal and other water movements also permit occupation of the same site-specific niche at successive moments in time. A site-specific niche is usually not an ecological niche in the sense of the Gause-Volterra principle of competitive exclusion.

The question therefore remains: what is so special about mangroves? The answer is two-fold: 
1. unlike many other marginal ecosystems, they are highly productive and interact intensely with other ecosystems; 2. natural mechanisms of healthy mangrove forests are a sink of heavy metal pollutants and probably of other toxic compounds or unfavorable $\mathrm{pH}$ levels.

About 1., we may recall that the exchange of matter and energy between a marginal ecosystem and the world around it is usually not very great. Mangroves are an exception in that exchanges with other ecosystems are not restricted to its neighbours. Because of tidal, coastal, and oceanic currents, particulate and dissolved organic matter produced or broken down in the mangroves can reach considerable distances from the point of origin. As an example, we may recall that in a deep oceanic trench in the Caribbean, a colony of sea-urchins was found living at a great depth and with guts filled with the remains of mangrove leaves. Internal entropy of the mangrove ecosystem is believed to be very high, with intensive recycling due to high physical and chemical dynamism and high temperatures. Though not continuously and not at all times, most mangroves export nutrients downstream to coastal waters; there is also sinking of organic matter that with time becomes stored energy such as turf. Mangroves offer shelter and are convenient nursery grounds for many species particularly of fish and crustaceans; they contribute to the siltation process that eventually creates new islands; they provide feeding and nesting opportunities for aerial fauna and have many other interactions with other systems. Over geological Eras, mangroves colonized all suitable coastal areas of the tropics and have entered the subtropics along the eastern coastal zone of the continents of the Southern Hemisphere, including Australia. Even the young Atlantic Ocean was colonized by mangrove species and has one, perhaps two, endemic species along its American shoreline.

The $2^{\text {nd }}$ feature of mangrove trees and shrubs which probably evolved from the need to adapt to soil unsuitable from the physical, chemical, and physico-chemical points of view, is the potential of mangrove trees for immobilizing heavy metal pollutants. It has recently been shown (Lacerda, 1998) that: "Mangrove plant physiology appears to cope with high salinity of pore waters and to hamper heavy metal absorption. As a result, heavy metal concentrations are located in areas very low in mangrove plants and animals. However, the immobilization mechanism only works when the mangrove ecosystem retains its natural conditions. Deforestation or degradation of mangrove forest will result in mobilization of accumulated heavy metals, ultimately resulting in their presence in coastal food chains. Therefore, conservation of mangrove ecosystems transcends the biodiversity issue, since it can also significantly contribute to maintenance of the environmental health of tropical coastal areas".

Mangroves offer free of cost a very large number of direct and indirect benefits for the health of man and the environment. Mangrove ecosystems are indeed very special, but it has taken a long time for man to understand that they can give very high returns if, but only if they are used rationally according to the characteristics of the sites were they are found. We must always remember that they are very fragile ecosystems. It is time, if not too late already, that we embark on serious long term program of rational management of mangrove ecosystems, for the sake of coastal zones and coastal marine waters, all over the world but specially in densely populated areas. Management must be appropriate to the characteristics of each mangrove site. Handle with care; mangroves are indeed very special.

\section{REFERENCES}

There is no scientific truth in this paper that has not been already published in the literature or that cannot be found in Glomis database. Basic knowledge about mangroves is considered here from a purely ecological point of view which, the author hopes, will be profitable for all those concerned the preservation, health, and rational use of the mangroves on a long-term sustained and sustainable basis. The important reference to be added here is the recent publication by:

LACERDA, L. D. de, 1998, Trace Metals Biogeochemistry and Diffuse Pollution in Mangrove Ecosystems. Mangrove Ecosystems Occasional Papers, n. 2. Okinawa, Japan, ISME, 65p. 